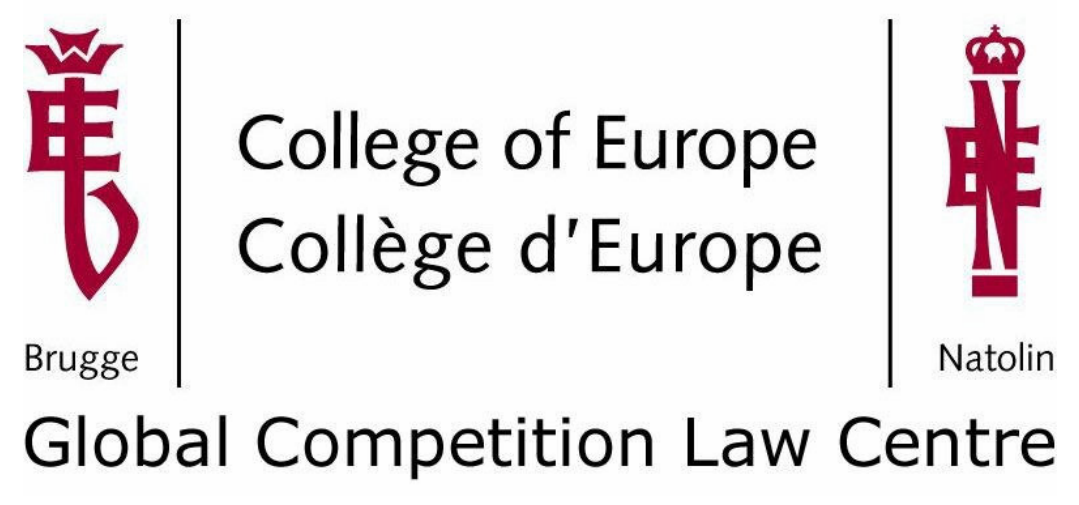

Research Paper on the Modernization of Article 82 EC

July 2005

\title{
The Concept of Dominance in EC Competition Law
}

Damien Geradin, Paul Hofer, Frédéric louis, Nicolas Petit, Mike Walker 


\title{
The Concept of Dominance in EC Competition Law
}

\author{
Damien Geradin, Paul Hofer, Frédéric Louis, Nicolas Petit and Mike Walker *
}

\section{Introduction}

The first prong of Article $82 \mathrm{EC}$ requires, prior to the identification of abusive behaviour, evidence that the firm under scrutiny enjoys a dominant position. Surprisingly, this issue seems to be sometimes overlooked. Enforcers, practitioners and scholars have recently paid greater attention to the concept of abuse than to the question of dominance when discussing Article 82 EC. This should not, however, be interpreted as a sign that the law of dominance is clear. Quite to the contrary, the concept of dominance raises a wide array of questions which are discussed in the sections that follow. Following this introduction, section II discusses the definition of dominance. Section III reviews the factors for establishing dominance. Finally, section IV makes comments on the concept of collective dominance.

\section{The Definition of Dominance}

\section{A. The definition of dominance stemming from case -law}

The term "dominance" is a legal concept. Yet, the assessment of dominance is ultimately very heavily influenced by economic considerations. This requires the identification of corresponding legal and economic concepts.

In the seminal United Brands and Hoffmann-La Roche cases, the Court defined dominance as:

"a position of economic strength enjoyed by an undertaking which enables it to prevent effective competition being maintained on the relevant market by affording it the power to behave to an appreciable extent independently of its competitors, customers and ultimately of its consumers."

Damien Geradin is Director of the Global Competition Law Centre, Professor at the University of Liège and at the College of Europe; Paul Hofer is Senior Consultant at Nera Economics Consulting; Frédéric Louis is Partner at Wilmer, Cutler Pickering Hale and Dorr; Nicolas Petit is Maître de Conférences at the University of Liège; Mike Walker is Vice-President, Charles River Associates.

1 Judgment of the European Court of Justice, Case 27/76, United Brands v. Commission, [1978] E.C.R. 207 at para. 65 and Judgment of the European Court of Justice, Hoffmann La Roche v. Commission, 85/76, [1979] E.C.R.-461 at para. 38. This definition has since then been repeatedly used by the Commission and the Community judicature in most Article 82 EC judgments, see Judgment of the European Court of Justice, Case C-171/05, Piau v. Commission para. 109, not yet reported, Judgment of the European Court of First Instance, Case T-219/99, British Airways v. Commission, not yet reported, at para. 189, Judgment of the 
Certain authors have seen two elements in this definition, namely (i) the power to behave independently of competitors, customers and consumers; and (ii) the ability to prevent effective competition being maintained on the relevant market. ${ }^{2}$ However, as Neven, Nutall and Seabright have rightly observed, it seems that on the legal ground, these elements are simply one and the same thing. ${ }^{3}$ This is confirmed by the rulings of the Community Courts which have never drawn any distinction between these elements.

Nonetheless, the formulation used by the ECJ is not entirely satisfactory. The concept of "acting independently" does not provide an adequate basis for discriminating between dominant firms and non-dominant firms. No firm can act to an appreciable extent independently, since every firm will be constrained by its respective demand curve. First, every firm is limited in its commercial behaviour to some extent by competitors since the presence of these competitors affects the firm's demand curve. Although this is by definition true for firms operating in a competitive market, it is also true for a dominant firm. All firms, including those that are held to be dominant, will increase prices to the point at which further price increases would be unprofitable. In this sense, competitors do constrain the behaviour of firms so that even a dominant firm does not act independently of its competitors. ${ }^{4}$ Second, an individual firm's demand curve is equally affected by the behaviour and preferences of its customers. Firms typically face downward sloping demand curves, indicating that a higher price comes at the expense of fewer sales: it is not generally open to a firm to raise prices and sell the same quantity as before. Again, this is true of a dominant firm just as much as it is true of a non-dominant firm. ${ }^{5}$

There is, of course, one important sense in which a dominant firm can act to an appreciable extent independently of its competitors. A dominant firm can increase its price above the competitive level and so can to some extent act independently at the competitive price. As Professor Whish notes, "the ability to restrict output and increase price derives from independence or, to put the matter another way, freedom from competitive constraint."6 However, there is a measurement problem here: how can one measure whether a firm has the ability to price above the competitive price level? The competitive price level is virtually always impossible to calculate (on both conceptual and data grounds). More fundamentally, if it could be routinely calculated then the identification of a dominant position would

European Court of First Instance, Case T-65/98, Van den Bergh Foods v. Commission, [2003] E.C.R. II4653, at para. 154, Case C-396/96 Compagnie Maritime Belge Transports v. Commission, [2000] E.C.R. I1365 at para. 34, Case T-128/98 Aéroports de Paris v Commission [2000] E.C.R. II-3929, at para. 147.

2 See R. Whish, Competition Law, $5^{\text {th }}$ Ed. LexisNexis-Butterworths, 2005 at p.179 and S. Bishop and M. Walker, The Economics of EC Competition Law, $2^{\text {nd }}$ Ed. Sweet and Maxwell, London, 2002 at para. 6.06:

3 See D. Neven, R. Nutall and P. Seabright, Merger in Daylight - The Economics and Politics of European Merger Control, CEPR, 1993 at p.18. Rather, when one of these conditions is satisfied, the Courts have tended to infer the satisfaction of the other. Some consider that these two elements are equivalent.

4 This seems to be understood in the case law as the Community courts have constantly held that the existence of some form of competition in a market did not necessarily rule out a finding of dominance. See Judgment of the European Court of Justice, United Brands, supra note 1 at paras. 113-121 and HoffmannLa Roche, supra note 1 at paras.39, 69-78.

5 Equally, when a firm's customers are not the end consumers (e.g., wholesale markets), the firm is still not able to behave independently of consumers. This is because demand for intermediate goods is a "derived" demand, i.e. it is ultimately determined by end consumers.

6 R. Whish, Competition Law, $5^{\text {th }}$ Ed., Butterworths, 2003 at p.179. Other interpretations have also been proposed. Professor Motta observes that behaving independently of its competitors might be formalized where the (dominant) firm maximizes its profits taking into account the best replies of its competitors. See M. Motta, Competition Policy - Theory and Practice, Cambridge University Press, (2004) at note 88. 
become redundant, since one could simply adopt the rule that all market participants are required to price at the competitive level.

\section{B. The economic approach - dominance as substantial market power}

For these reasons, a better economic test for identifying a dominant position lies in the other part of the definition of dominance, i.e. a firm's ability to engage in business activities that "prevent effective competition from being maintained".

From an economic perspective, competition can be said to be effective when no firm, either acting individually or in concert, is able to exercise substantial market power. The standard definition of market power is the ability to profitably raise price (through the restriction of output) above the level that would prevail under competitive conditions. This definition is already used by a number of competition authorities. For instance, the European Commission considers that "market power is essentially measured by reference to the power of the undertaking concerned to raise prices by restricting output without incurring a significant loss of sales or revenues". 7 The UK Office of Fair Trading (hereafter, the "OFT") has also adopted a close definition. It refers to market power as "the ability to raise prices consistently and profitably above competitive levels". ${ }^{8}$

However, the existence of market power is not a zero-one matter. Market power is a continuum and a very large number of firms possess some degree of market power. ${ }^{9}$ Dominance should therefore apply only to those firms that possess substantial market power or a very high degree of market power. ${ }^{10}$ It is worth noting that the equating of dominance with substantial (or significant) market power is already made in the definition of dominance formulated by the ECJ. The reference to the ability for a firm to behave independently to an "appreciable extent" indicates that Article 82 EC is not concerned with the minimal amount of market power that most firms enjoy. ${ }^{11}$ A similar principle has been recognized in sector specific legislation where the Council and the Parliament explicitly use "significant market power" and dominance as synonyms. ${ }^{12}$ Furthermore, in the UK the OFT has indicated that "an undertaking is unlikely to be dominant if it does not have substantial market power". ${ }^{13}$

7 See Commission Working Document on the Proposed New Regulatory Framework for Electronic Communications Networks and Services: Draft Guidelines on market analysis and the calculation of significant market power (2001) at para. 65. See also Commission Notice - Guidelines on Vertical Restraints, (2000) O.J. C 291, pp.1-44 where the Commission defines market power as "the power to raise price above the competitive level and, at least in the short term, to obtain supra normal profits". Scholars have endorsed a similar definition. Mehta and Peeperkorn state that "The answer given by economists on the first question - what is market power? - concentrates on the power to raise price above the competitive level." Paragraph 1.18 of K. Mehta and L. Peeperkorn (2000).

8 See para. 1.2 of the Guidelines of the OFT on the Assessment of Market Power, OFT415, 1999.

$9 \quad$ See R. Posner, Antitrust Law, $2^{\text {nd }}$ Ed., University of Chicago Press, 2001 at p.265; D.W. Carlton and J. M. Perloff, Modern Industrial Organization, Scott, Foresman/Little, Brown 1989 at 738. It can be so because of product differentiation, switching costs, consumer fidelity etc. See M. Motta supra note 6 at pp.115-116. Only in the theoretical model of perfect competition or in the Bertrand model with homogeneous products would firms enjoy no market power.

10 See M. Motta, supra note 6 at p.35.

11 See I. Van Bael and J. F. Bellis, Competition Law of the European Community, $4^{\text {th }}$ Ed., (2005) Kluwer Law International at para. 2.23.

12 See Article 14(2) of Directive 2002/21/EC of the European Parliament and of the Council of 7 March 2002 on a common regulatory framework for electronic communications networks and services, (2002) O.J. L 108, which provides: "An undertaking shall be deemed to have significant market power if, either 
In contrast, the European Commission has not explicitly commented on this issue of substantiality. However, it has indirectly equated dominance to substantial market power. The guidelines on the application of Article 81(3) provide for instance that:

"Market power is a question of degree. The degree of market power normally required for the finding of an infringement under Article 81(1) in the case of agreements that are restrictive of competition by effect is less than the degree of market power required for a finding of dominance under Article 82". ${ }^{14}$

As a matter of policy, the Commission should be encouraged to explicitly clarify that dominance within the meaning of Article $82 \mathrm{EC}$ amounts to substantial market power.

The question then immediately turns on what counts as substantial market power, as opposed to insubstantial or insignificant market power. Scholars and competition law enforcers have identified two forms of substantial market power.

A first form of substantial market power concentrates on the "power over price" ${ }^{15}$ But in terms of its implementation, this concept does not say how much power over price there must be (i.e. by how much must a dominant firm be able to raise price above the competitive level) to distinguish substantial market power from insubstantial market power. A one-way test can be inferred from the market definition SSNIP methodology used by the Commission. This provides that a group of products forms a relevant market if a hypothetical monopolist can profitably impose a Small but Significant Non-transitory Increase in Price above the competitive level, whereby the "small but significant" is typically taken to mean $5-10 \% .{ }^{16}$ On that basis, if a firm is in fact able to profitably implement a 5-10\% price rise, it follows automatically that the products controlled by that firm already by themselves represent a relevant market, thus making the firm a monopolist. On the basis that a monopolist can safely be assumed to be dominant, it would follow that the ability to raise price by $5-10 \%$ amounts to a sufficient degree of "power over price" for a finding of dominance.

The concept of "power over price" is, however, not entirely satisfactory. First, it underplays the fact that substantial market power can be exercised on many other factors such as, for instance, quality, service and innovation. ${ }^{17}$ Thus, a definition of substantial market power should also encompass the ability to lower quality or reduce the pace of innovation.

individually or jointly with others, it enjoys a position equivalent to dominance, that is to say a position of economic strength affording it the power to behave to an appreciable extent independently of competitors, customers and ultimately consumers".

13 See para. 2.10 of the Guidelines of the OFT on the Assessment of Market Power (OFT 415).

14 See Communication from the Commission - Guidelines on the application of Article 81(3), (2004) O.J. C 101, pp.97-118 at para. 26. See also the Guidelines on Vertical Restraints "Companies may have market power below the level of market dominance, which is the threshold for the application of Article 82".

15 The abuse of dominance in terms of excessive or exploitative prices is closely related to this category of market power.

16 See OFT and Competition Commission merger guidelines, supra note 8.

17 See J. Azevedo and M. Walker at p.365. This has been recently recognised by the European Commission in its Guidelines on the Application of Article 81(3) of the Treaty where it states that market power is the ability to maintain prices above competitive levels for a significant period of time or to maintain output in terms of product quantities, product quality and variety or innovation below competitive levels for a significant period of time", at para. 25. 
Second, the suggested definition of this concept requires the identification of the competitive price level which is a notoriously daunting task. It is indeed virtually impossible to determine the competitive price level, and if that was possible, there would be no need to be concerned with the concept of dominance. Hence, a test articulated on the "ability of a firm to restrict output substantially in the market place, below its current level" would probably be better suited for the purpose of identifying a substantial market power. If a firm is able to restrict significantly total output in the market by restricting its own output, this indicates that other firms are unable to replace the supply taken away by the allegedly dominant firm. This implies that there are both barriers to entry and barriers to expansion, which suggests that a firm with a large market share may well have substantial market power.

A second form of market power is the "power to exclude". As Krattenmaker, Lande and Salop put it, this form of market power can be found where:

"[a] firm or group of firms may rise price above the competitive level or prevent it from falling to a lower competitive level by raising its rivals' costs and thereby causing them to restrict output. Such allegations are at the bottom of most antitrust cases in which one firm or group of firms is claimed to have harmed competition by foreclosing or excluding its competitors. We denote this power as "exclusionary" [...] market power". ${ }^{18}$

This form of market power is already explicitly taken into account by a number of competition authorities, including the OFT which states that "[a dominant firm] can also use its market power to engage in anti-competitive conduct and exclude or deter competitors from the market". ${ }^{19}$ Examples of such exclusionary behaviour include predatory pricing, ${ }^{20}$ certain forms of loyalty rebates, refusal to supply, and margin squeeze.

In the context of Article 81(3) EC, the Commission has itself recognized that:

"The creation, maintenance or strengthening of market power can [...] also result from a restriction of competition between any one of the parties and third parties [to an agreement], e.g. because the agreement leads to foreclosure of competitors or because it raises competitors' costs, limiting their capacity to compete effectively with the contracting parties.".

While the Commission recognizes this type of behaviour as an abuse concept under Article 82 , it has not clarified the analytical framework that it applies to such cases. In fact, the Commission has at times been accused of protecting competitors, instead of protecting competition and consumers. $^{22}$

\section{Levels of dominance}

18 T.G. Krattenmaker, R.H. Lande, and S.C. Salop, "Monopoly Power and Market Power in Antitrust Law" (1987), 76, Georgetown Law Journal, 241 at p.28.

19 See "The Chapter II Prohibition", OFT 402, 1999 at para. 3.9.

20 It can be argued that a dominant position is not necessary for a strategy of predation; in fact, a position of dominance is the end goal of predation, and not the starting point. If a firm were already dominant, there is arguably little need to predate.

21 See Communication from the Commission - Guidelines on the application of Article 81(3), supra note 14 at para. 26.

22 See R. Whish, supra note 2 at p. 20. 
The economic approach to defining dominance does not preclude drawing distinctions between different levels/degrees of dominance. In fact, one firm may be able to price well above the competitive level for a long time, while another firm may only be able to price just above for a short period of time. ${ }^{23}$ From an economic perspective there is no difficulty with such a sliding scale. As noted above, market power should be understood as a continuum, rather than as a zero-one state. Accordingly, a dominant firm can be viewed as one with substantial market power and there is no logical difficulty with the fact that there are different levels of "substantial".

A firm enjoying a quasi monopoly could thus be found in a position of "super-dominance". This concept was for the first time referred to by Advocate General Fennelly in the Compagnie Maritime Belge case:

"To my mind, Article 86 [now Article 82] cannot be interpreted as permitting monopolists or quasi-monopolists to exploit the very significant market power which their superdominance confers so as to preclude the emergence either of a new or additional competitor. Where an undertaking, or group of undertakings [...] enjoys a position of such overwhelming dominance verging on monopoly, comparable to that which existed in the present case at the moment when $\mathrm{G} \& \mathrm{C}$ entered the relevant market, it would not be consonant with the particularly onerous special obligation affecting such a dominant undertaking not to impair further the structure of the feeble existing competition for them to react, even to aggressive price competition from a new entrant, with a policy of targeted, selective price cuts designed to eliminate that competitor". ${ }^{24}$

The rationale behind "superdominance" is that if a firm with 50 per cent of a market is dominant, then a firm with 90 per cent - other things being equal - is likely to be even more dominant. $^{25}$ So far, this concept has, however, never been explicitly endorsed by the Community courts. Rather, the Courts have only expressed discreet support for the idea. In Tetra Pak II, for instance, the CFI and the ECJ implied that a dominant position could be easily identified where the undertaking under scrutiny enjoyed a quasi monopoly. ${ }^{26}$ Similarly, but without being more explicit, the Commission expressed this view in the 1998 Football World Cup, ${ }^{27}$ as well as in the Microsoft decisions where it held:

23 See T. Krattenmaker, K. Lande and S. Salop supra note 18 at p.247.

24 See Opinion of Advocate General Fennelly delivered on 29 October 1998 in Compagnie maritime belge transports SA (C-395/96 P), Compagnie maritime belge SA (C-395/96 P) and Dafra-Lines A/S (C-396/96 P) $v$ Commission, Joined cases C-395/96 P and C-396/96 P, [2000] E.C.R. I-1365 at para. 137.

25 The legal logic is also that the special responsibility of super dominant firms is higher than that of dominant firms.

26 See Judgment of the European Court of First Instance, Case T-83/91, Tetra Pak Rausing v. Commission, [1994] E.C.R. II-755 at para. 115: "The actual scope of the special responsibility imposed on an undertaking in a dominant position must therefore be considered in the light of the specific circumstances of each case, reflecting a weakened competitive situation, as an analysis of the case-law confirms". See Judgment of the European Court of Justice, C-333/94, Tetra Pak International SA v Commission, [1996] E.C.R. I-5951 at para. 31 "Accordingly, the Court of First Instance was right to accept the application of Article 86 [now Article 82] of the Treaty in this case, given that the quasi-monopoly enjoyed by Tetra Pak on the aseptic markets and its leading position on the distinct, though closely associated, non-aseptic markets placed it in a situation comparable to that of holding a dominant position on the markets in question as a whole."

27 Commission decision of 20 July 1999, 1998 Football World Cup (2000) O.J. L 5 at paras. 86-87: "The scope of the parties' responsibility must therefore be considered in relation to the degree of dominance held by the parties and to any special characteristics of the market which might affect the competitive situation. [...] the CFO was, as a de facto monopolist, under a prima facie obligation to ensure that entry tickets sold in 1996 and 1997 for finals matches were made available to the general public under non-discriminatory 
"Microsoft, with its market shares of over 90\%, occupies almost the whole market. It therefore approaches a position of complete monopoly, and can be said to hold an overwhelmingly dominant position",28

However, absent any clear statement by the Court and the Commission on the concept of super dominance, it would be indeed helpful if the Commission could clarify this issue. ${ }^{29}$

\section{Market definition}

There are serious problems with market definition in Article 82 cases. A first problem concerns the substantive test for the identification of relevant markets. The Commission's Guidelines on the Definition of the Relevant Market made it clear that the standard economic approach to defining a relevant market is the SSNIP test (or Hypothetical Monopolist test). ${ }^{30}$ However, while this test is well suited to merger cases, the test seems poorly suited to dominance cases. Broadly speaking, the correct benchmark for Article 82 cases is the price which would prevail in the absence of any anti-competitive behaviour. But this varies with the particular allegation. For instance, if the allegation is one of excessive pricing, then the benchmark is the price in the absence of the alleged excessive pricing. However, this approach amounts to circular reasoning, because it is impossible to form a view on this benchmark without first forming a view on whether the prevailing prices are excessive. If the allegation is unfounded, then the correct benchmark is the current price. If the allegation is founded, then the correct benchmark is a lower price. ${ }^{31}$ But without knowing whether the allegation is unfounded or not, one cannot know what the benchmark is. And if it is already known whether the allegation is unfounded or not, why is there a need for market definition? This implies that in many Article 82 cases market definition may not be as useful as generally believed. ${ }^{32}$ However, as a matter of law, the ECJ made clear in Continental Can that market definition was essential for the assessment of dominance within Article 82 proceedings. ${ }^{33}$

arrangements throughout the EEA, even though demand from consumers outside France for certain ticket products may have been relatively small as against the demand from the general public in France." Competition Law, (1997) O.J. C 372 1at paras. 17-18.

Otherwise, the analysis will suffer the pitfalls known under the name of the Cellophane Fallacy. Implementing the SSNIP test from the monopoly price would lead to defining the relevant market too widely, thereby erroneously reaching the conclusion that the firm under scrutiny does not enjoy a dominant position. This is acknowledged in the Commission's Guidelines, supra note 7 at para. 19: "Generally, and in particular for the analysis of merger cases, the price to take into account will be the prevailing market price. This might not be the case where the prevailing price has been determined in the absence of sufficient competition. In particular for investigation of abuses of dominant positions, the fact that the prevailing price might already have been substantially increased will be taken into account". The Commission, however, remains silent on the precise manner in which the cellophane fallacy will be taken into account.

32 See S. Baker and L. Wu, "Applying the Market Definition Guidelines of the European Commission", (1998) 19 E.C.L.R. 277; D. Harbord and G. Von Graevenitz, "Market Definition in Oligopolistic and Vertically Related Markets: Some Anomalies", (2000) 3 E.C.L.R. 151 at note 6; F. M. Fisher, "Diagnosing Monopoly", (1979) 19, Quarterly Review of Economics and Business, 7 at p.16; F. Fishwick, "The definition of the relevant market in the competition policy of the EEC", (1993) 1 Revue d'économie industrielle, 63.

33 See Judgment of the European Court of Justice, Case C-6/72, Europemballage Corporation and Continental Can Company Inc. v Commission, [1973] E.C.R. 215 at para. 32: "For the appraisal of SLW's dominant position and the consequences of the disputed merger, the definition of the relevant market is of 
There are, however, a number of ways of dealing with the problem of identifying the appropriate price benchmark for the SSNIP test:

Price concentration studies. If data is available covering a number of different geographic areas, and concentration levels and market shares vary across these areas (with minimal differences in all other respects), then the relationship between price and concentration / market shares across the areas can be informative. If a firm is accused of being dominant because it has $60 \%$ of the market for widgets, then evidence that the price of widgets does not vary with concentration across the regions is useful as it suggests that widgets is not a relevant market, which in turn suggests that the $60 \%$ figure does not imply dominance.

$>$ Inferences on market definition from behaviour. The analysis of behaviour by an allegedly dominant firm may provide information about market definition. If an effects analysis shows that the firm was able to price excessively, then this implies the firm is dominant, which in turn is likely to imply a particular market definition. But in that respect, defining the relevant market prior to the assessment of the alleged behaviour has no purpose. ${ }^{34}$

$>$ Resort to a "traditional" characteristics approach to market definition. ${ }^{35}$ Although such an approach has (rightly) gone out of fashion in borderline cases, there are situations when it can provide "upper bound" or "lower bound" benchmarks. For example, the traditional market definition approach may allow the investigator to dismiss the allegation immediately if the allegedly dominant firm has a very small market share of all plausible markets. Equally, if the firm has a very large share of all plausible markets, this suggests that the firm may well be dominant.

All three methods have some merit, and are likely to support each other, rather than leading to different conclusions. The choice as to which is most appropriate in a given case is likely to depend on the precise circumstances. For example, price-concentration analysis is particularly useful if there are comparable "benchmarks", but less appropriate if the various areas are characterised by different demand levels or costs. Equally, the traditional approach is useful if it leads to clear-cut outcomes, but is less reliable in borderline cases.

A second problem relates to the market definition practice of the European Commission under Article 82 EC. There has indeed been a great deal of criticism of the fact that the Commission often defined markets very narrowly with a consequence that the firm under scrutiny was inevitably found in a dominant position. ${ }^{36}$ This has been observed, for instance,

essential significance, for the possibilities of competition can only be judged in relation to those characteristics of the products in question by virtue of which those products are particularly apt to satisfy an inelastic need and are only to a limited extent interchangeable with other products". See D. Harbord and G. Von Graevenitz, supra note 32 at p.152.

35 The traditional approach focuses on the review of, among others, products characteristics, prices and intended use from the consumer's viewpoint. An example of this approach can be found in the Block Exemption Regulation 2790/1999 of 22 December 1999 on the application of Article 81(3) of the Treaty to categories of vertical agreements and concerted practices, (1999) O.J. L 336/21.

36 See, for instance, M. Utton, Market Dominance and Antitrust Policy, Edgar Elgar, Cheltenham UK, 2003 at p.79. 
in the United Brands and Hugin decisions, or in the Michelin I case. ${ }^{37}$ This risk is further reinforced by the fact that, since the adoption of the Guidelines on the definition of the relevant market, the Commission has manifestly not applied the SSNIP test but rather preferred to rely on a qualitative assessment of substitutability through the identification of a cluster of indicators. ${ }^{38}$

\section{Factors for Establishing Dominance}

Traditionally, the EC Courts and the Commission have found dominance on the basis of a review of market shares and an assessment of additional "factors". There is, however, much uncertainty as to the value of market shares as an indicator of dominance, as well as to the relationship between market shares and the "other" factors. Such lack of a clear analytical framework is detrimental to the rigour of the analysis conducted to assess dominance. In particular, there is a risk that the analysis of factors indicative of dominance is reduced to a "checklist" approach, where a number of factors are examined in turn, in no particular order and without it being clear how much weight each individual factor carries, to conclude, on the basis of a plurality of factors being met, that the undertaking under investigation is dominant.

Such a simplistic approach must be firmly rejected. A finding of dominance requires a careful assessment of market conditions, in what must necessarily be a case-by-case analysis. In this analysis, market shares, while being a useful first indicator, cannot by themselves be decisive. The case law has, to a certain extent, already recognized this. Any advance in this respect is, however, clearly predicated on the Commission leading the way to define a consistent analytical framework for the assessment of dominance.

A. The treatment of market shares in the case-law and the Commission's decisionalpractice

Market shares are undoubtedly a useful preliminary tool in assessing market power. Market shares alone, however, cannot be sufficient for a finding of dominance. Market shares are a poor tool for measuring e.g. the constraints posed by potential competition, for adequately ascertaining the conditions of competition in innovative markets, or for properly taking into account the fact that some bidding markets may be characterized by intense competition despite the presence of large market shares, to name but a few examples.

Market shares are an imperfect proxy for measuring market power, and on their own cannot justify a finding of dominance. ${ }^{39}$ If it is accepted that high market shares alone cannot be

37 Id and V. Korah, EC Competition Law and Practice, $8^{\text {th }}$ ed, Hart Publishing, Oxford-Portland Oregon, 2004 at pp.99-101.

38 This tendency can be observed, for instance, in the Microsoft decision, supra note 28.

39 For instance, if entry and exit were costless and very easy, then even a monopolist might not be able to raise prices above the competitive level because the mere threat of entry would keep prices low. Similarly, market shares are often only weak indicators of market power in bidding markets. In bidding markets buyers offer a number of firms the chance to be their preferred supplier by bidding the lowest price. Suppliers therefore bid based on their own costs and on their expectations of what others will bid. In markets of this type, firms that have previously won only a modest number of contracts or perhaps have never previously won a contract - as would be the case if the firm were a new entrant - can affect the price at which contracts are awarded. What matters is not market share but the ability to submit a credible bid. 
determinative for a finding of market power, it follows that the need to take into consideration additional factors (barriers to entry, buyer power) will apply regardless of whether market shares are very high - even close to a monopoly - or not.

In Hoffmann-La Roche, the European Court of Justice ("the ECJ") had this to say about market shares:

"[...] although the importance of the market shares may vary from one market to another the view may legitimately be taken that very large shares are in themselves, and save in exceptional circumstances, evidence of the existence of a dominant position.

An undertaking which has a very large market share and holds it for some time, by means of the volume of production and the scale of the supply which it stands for - without those having much smaller market shares being able to meet rapidly the demand from those who would like to break away from the undertaking which has the largest market share - is by virtue of that share in a position of strength which makes it an unavoidable trading partner and which, already because of this secures for it, at the very least during relatively long periods, that freedom of action which is the special feature of a dominant position". 40

While the ECJ does grant significant evidentiary value to high market shares, at the same time it shows an understanding of basic economic concepts. Market shares in themselves are meaningless without additional indicators that will reflect on the company's real position in the marketplace (e.g., position of strength over a relatively long period of time; existing barriers to entry or to expansion that prevent competition from meeting demand in the event of supra-competitive prices, etc.).

This nuanced approach to the concept of dominance was however revisited in subsequent case law, principally in $A K Z O$. In $A K Z O,{ }^{41}$ the ECJ only partly refers to its own HoffmannLa Roche ruling, to extract the conclusion that

"with regard to market shares the Court has held that very large market shares are in themselves, and save in exceptional circumstances, evidence of the existence of a dominant position [...] That is the situation where there is a market share of $50 \%$ such as that found to exist in this case".

$A K Z O$ thus appears to lead to a shift from the consideration of market shares as one among other indicators of dominance - albeit an important one - to over-reliance on market shares, which can on their own and save exceptional circumstances be sufficient for a finding of dominance. This narrow reading of $A K Z O$ is not in line with the much more prudent ruling in Hoffmann-La Roche. The problem however remains that, if a too generous interpretation of $A K Z O$ was promoted, companies may find themselves in a position of per se dominance due

Even a firm with a very low market share may still have a major effect on the bidding behaviour of other firms in the market as long as they bid credibly and aggressively. Accordingly, current market shares can provide a misleading picture as to the level of current competition. Highly variable market shares indicate that a high current market share may only be transient and suggest the existence of significant competition between firms, thus implying relatively little market power. Finally, the high market share of a firm may just reflect superior efficiency.

40 Judgment of the European Court of Justice, Case C-85/76, Hoffmann-La Roche v. Commission, supra note 1 at para. 41.

41 Judgment of the European Court of Justice, Case C-62/86, AKZO v. Commission, [1991] E.C.R. I-3359, at para. 60 . 
to their relatively high market shares, irrespective of the actual competitive market conditions they are facing.

The Commission itself appears to - rightly - have gone beyond a literal reading of $A K Z O$, and will normally consider other parameters in its assessment of whether a company is in a dominant position. The recent Microsoft Decision ${ }^{42}$ provides a good example of the Commission going beyond the mere review of market shares and attempting to determine on the basis of the particular circumstances of the markets under review whether Microsoft was in a position of dominance or not. Nevertheless, the fact that the Commission repeats in that case the mantra that very large market shares in excess of 50\% "are considered in themselves, and but for exceptional circumstances, evidence of the existence of a dominant position",43 does raise a risk that the Commission will not be held to highest standard of evidence in the way it treats the additional factors of dominance, since it itself considers that it may not be required to conduct such an analysis in the first place.

\section{B. Market shares and the burden of proof}

The importance given to market shares in assessing dominance is closely connected to the issue of who bears the burden of proof regarding the existence of market power. The case law referred to above appears to hinge on the notion of very large market shares. Again, a literal reading of the case law would seem to imply that, in cases where very large market shares are involved, the onus of rebutting the initial presumption of dominance based on a market share of $50 \%$ or more would lie with the company alleged to be dominant, and not with the Commission. In our view, this shift in the burden of proof based on the sole finding of a "very large" market share would be impracticable, and cannot be justified on the basis of a coherent division of the responsibilities between, on the one hand, the public authority responsible for conducting the investigation and, on the other hand, the company under investigation. If market shares are by definition an imperfect proxy for a finding of market power, any shift of the burden of proof at that early a stage in the analysis from the Commission to the company subject to an Article 82 EC investigation can simply not be sustained.

Again, although the Commission does not end its assessment with the finding of a very large market share, the impression is created in most cases that the rest of the analysis is apparently confined to looking for exceptional circumstances that would disprove the presumption obtained from the sole analysis of market shares, rather than the thorough analysis of market conditions which would be required to substantiate a finding of dominance.

\section{C. $\quad$ Assessment of market shares in practice}

A number of additional points need also to be mentioned when considering market shares.

\footnotetext{
42 Commission decision Microsoft, supra note 28 at paras. 428-541. This paper argues that the framework for the analysis of dominance as set out by the Commission in its Microsoft Decision was the correct one. It does not take a view as to the correctness of the Commission's findings in that case.

43 Id. at para. 435 .
} 
While low market shares alone cannot in themselves suffice to eliminate concerns about the existence of dominance, it is suggested that, at the very least, the fact that say $60 \%$ or more of the relevant market remains open to competition should - unless there is strong evidence to the contrary - be prima facie indicative of the absence of market power. ${ }^{44}$ A de minimis rule of this kind has, for instance, been proposed by the OFT in its "Assessment of Market Power" guidelines. $^{45}$

It is undisputed that market shares cannot be viewed in isolation. Earlier case law and consistent Commission practice confirm that the market shares of a company need at the very least to be assessed in relation to the market shares of competitors active in the relevant product/geographic markets.

The reference to market shares cannot be a static exercise, but should be appraised over a timeframe that is sufficiently indicative for the market shares to prove meaningful. ${ }^{46}$ While what constitutes a reasonable timeframe needs to be addressed on a case-by-case basis, it is suggested that any period less than 3-5 years is unlikely to be sufficient for market shares to be used even as an initial indicator of market power.

Despite some suggestions to the contrary by both the Commission and EC Courts, ${ }^{47}$ it is argued that a constant decline of market shares in the company that is alleged to be dominant be factored in when determining whether a company is really capable of exerting market power. $^{48}$

\section{The "unavoidable trading partner" concept}

Much has been made by some of the use of the concept of "unavoidable trading partner" in recent Court judgments and Commission decisions ${ }^{49}$. It should be recalled that, as such, this concept is not new as the ECJ already mentioned it in the above quoted passage of its Hoffmann-La Roche judgment. In our view, the concept as such adds little, and is in fact

44 In Hoffman-La Roche, the ECJ annulled the Commission's decision that Roche was dominant in the vitamin B3 market as its share of this market amounted to $43 \%$ and there were no additional factors, which contributed to establish a finding of dominance. However, in its Virgin/British Airways, BA was held dominant in the UK air travel agency services market with a market share of $39.7 \%$. This was, however, the first time that a firm with a market share below $40 \%$ was found to be dominant.

45 See Section 2.12 of the guidelines, supra note 8 ("The OFT considers that it is unlikely that an undertaking will be individually dominant if its share of the relevant market is below 40 per cent, although dominance could be established below that figure if other relevant factors (such as the weak position of competitors in that market and high entry barriers) provided strong evidence of dominance").

46 Id. at 4.3 ("The history of the market shares of all undertakings within the relevant market is often more informative than considering market shares at a single point in time, partly because such a snapshot might not reveal the dynamic nature of a market. For example, volatile market shares might indicate that undertakings constantly innovate to get ahead of each other, which is consistent with effective competition. Evidence that undertakings with low market shares have grown rapidly to attain relatively large market shares might suggest that barriers to expansion are low, particularly when such growth is observed for recent entrants").

47 See Judgment of the European Court of First Instance, Case T-219/99, British Airways v. Commission, not yet reported, para. 224 and para. 298; see also Commission decision of 14 July 1999, Virgin/British Airways, (2000) O.J. L30/1, para. 107.

48 It is however recognized that declining market share might also be a consequence of abusive behaviour, e.g. in an investigation on excessive pricing.

49 See recently Judgment of the European Court of First Instance, British Airways v. Commission, not yet reported, para. 217 and Commission decision of 20 June 2001, Michelin, (2002) O.J. L 143/1, at paras. 200208. 
equivalent to asserting that a company has market power over its customers, which is part of the legal definition of dominance. At most, the consideration that a company may be an "unavoidable trading partner" will assist the Commission in identifying the relevant parameters - outside market shares - that are relevant for a finding of dominance in the particular industry under examination (e.g., barriers to entry linked to a must stock brand, barriers to entry raised by the control of essential assets, etc.), i.e. the factors that make customers dependent upon the allegedly dominant player.

\section{E. The need to assess the existence of barriers to entry and to expansion}

As mentioned above, both the Commission and EC Courts have referred in their decisionmaking to a number of additional factors that may be indicative of dominance. So far, however, the analytical framework in which these factors must be assessed has been missing. As suggested by Professor Whish among others, these factors have to be seen as tools for determining whether the conditions prevailing on the market give rise to barriers to entry or barriers to expansion, thus allowing the allegedly dominant undertaking to behave to an appreciable extent independently of its competitors, customers and ultimately of consumers (or of suppliers in monopsony cases). ${ }^{50}$ If anyone can quickly enter and exit the market at will, even a $100 \%$ market share is irrelevant for an assessment of dominance.

Under the Hoffmann-La Roche and AKZO terminology, one may think that barriers to entry/expansion $^{51}$ are present on each and every market, since it would only be in "exceptional circumstances" that a company enjoying high market shares may not be in a position to exert market power" ${ }^{52}$. However, it is unlikely that a company with high market shares will have the possibility of sustaining supra-competitive prices in the long run if barriers to entry are low, because any decrease in output or any price increase could be subject to competitive reaction by the remaining (actual and/or potential) players on the relevant market. On such basis, should a fully-fledged analysis of market conditions reveal that there are no such barriers to entry, the fact that a company holds a large market share would not be sufficient for a finding of dominance. In those cases, the high market shares could be simply indicative of a "superior skill, foresight and industry" of the company subject to an investigation, ${ }^{53}$ or of the existence of external factors such as historic trends that may not be sustainable in the near future.

It is worth reiterating that a determination of whether or not there are barriers to entry requires a full analysis of the conditions of competition prevailing on the relevant market at a particular point in time. The fact that one or more of the factors listed below are present, suggesting the existence of an entry barrier, should not relieve the regulatory authorities of their duty to make a full determination of whether the allegedly dominant entity can really exercise market power. At the very least, any reference to the indicators detailed below should take into consideration whether the characteristics under examination are exclusive to the company that allegedly has market power, or whether these characteristics are shared by other players active on the relevant markets. While factually correct, statements such as those

$50 \quad$ See R. Whish, supra note 2.

51 Throughout the remainder of this section, the term "barriers to entry" will be understood as encompassing also barriers to expansion, unless otherwise specified.

52 Which is noteworthy since some economists would argue that true barriers to entry are in fact very rare.

53 The language is borrowed from Judge Hand in United States v. Aluminum Co. of America, 148 F. $2 \mathrm{~d} 416$ (1945). 
contained in some Commission decisions ${ }^{54}$ noting that "the existence of a dominant position may depend upon a combination of factors, where no single one is necessarily decisive" are unfortunately of little guidance to companies and practitioners. Again, the Microsoft Decision is a good example of a recent attempt from the Commission to shift from a pure "checklist" approach of a number of unweighted factors and delve into an analysis of the particular features of the industry prior to reaching a finding of dominance. ${ }^{55}$

In looking at the factors identified so far, we limit our analysis of past Commission and EC Court practice to some of the most prominent cases that highlight the EC position with regard to some of the key factors (e.g., Hoffmann-La Roche, United Brands, Michelin I and II) even though it is clear that for each of the factors the wealth of cases invoking them either directly or indirectly is much broader.

\section{Legal barriers to entry}

Legal/statutory barriers are relevant for determining whether a company is dominant on a given market. Undertakings enjoying exclusive rights to provide a given product or service (i.e., statutory monopolies) will by definition enjoy a dominant position as no other firm can enter in the market to challenge them. The same can be said of firms that enjoy intellectual property rights, which prevents other firms from producing a given product or service, unless there are alternative technologies, which allow other firms to produce the product or service in question (see below, Section 5.4). Thus, any detailed analysis of barriers to entry will require an understanding of the statutory/legal provisions under which a company that is allegedly dominant operates.

The existence of high market shares, if they are found in a market that has only been recently open to competition, may not be sufficiently reliable as an indicator of market power. Indeed, these market shares typically go down once competitors have entered the market. Thus, a position of substantial market power soon after liberalization does not necessarily mean that it will be maintained for a long time. On the other hand, legal barriers such as those arising from a restricted number of licenses being granted by government to operate on the relevant market, or by the requested adherence to technical standards that can only be complied with by one or a few companies that are driving the standard-setting process may provide some initial indication of the existence of market power. ${ }^{56}$

\section{$\underline{\text { Sunk costs and barriers to expansion }}$}

Sunk costs are costs that must be incurred in order to compete on a given market, and that are not recoverable upon exit. ${ }^{57}$ In United Brands, ${ }^{58}$ the ECJ noted that "the particular barriers to

54 See e.g., Commission decision of 13 December 2000, Soda ash-Solvay, (2003) O.J. L10/10, para. 128.

55 As stated above, this paper takes no view on the assessment actually carried out by the Commission in Microsoft.

56 For these and other illustrations, see OFT Guidelines, "Assessment of Market Power" supra note 8 as well as "Assessment of Market Power, Draft Competition Law Guidelines for Consultation" (OFT 415a, April 2004).

57 An important distinction can be made between exogenous and endogenous sunk costs. Exogenous sunk costs are those which any firm must incur if it is to enter the market. For example, exogenous sunk costs are those associated with set-up costs such as the acquisition of a plant with minimum efficient scale. In 
competitors entering the market are the exceptionally large capital investments required [...], the introduction of an essential system of logistics [...], economies of scale from which newcomers to the market cannot derive any immediate benefit and the actual cost of entry made up inter alia of all the general expenses incurred in penetrating the market such as the setting up of an adequate commercial network, the mounting of very large-scale advertising campaigns, all those financial risks, the costs of which are irrecoverable if the attempt fails". All this led to practical and financial obstacles to entry that placed United Brands in a dominant position.

While sunk costs can indisputably be a factor in determining the existence of barriers to entry, the fact that an industry is characterized by large sunk costs does not in itself automatically preclude the possibility of entry or of aggressive competition on the marketplace. This possibility may arise when there are no barriers to expansion of other operators already on the market. Indeed, barriers to entry relate to the ability of firms outside a particular market nonetheless to impose a constraint on the potential for exercising market power within the market. Barriers to expansion, on the other hand, relate to the ability of firms already operating in the market to impose a constraint on the potential for a firm or firms to exercise market power within the market. A barrier to expansion is something that stops a firm already in a market from being able quickly and cheaply to increase its output. Thus a firm that is capacity constrained and would have to incur significant sunk costs to expand its output faces a barrier to expansion, whereas one that currently has spare capacity does not face such a barrier to expansion (up to the point at which it is using all its capacity). Equally, a firm that is currently producing at full capacity may not face significant barriers to expansion if it can increase its capacity quickly and relatively cheaply (in particular, without incurring significant sunk costs). If rival firms in a market do not face barriers to expansion, then they are likely to be able to respond to a price rise imposed by another firm by undercutting the price rise and selling more output than previously, thus undermining the attempt by the original firm to raise prices profitably.

Barriers to expansion can be low even though barriers to entry are high. A failure to take account of barriers to expansion might lead to the erroneous conclusion that a firm with a high market share has market power because there are high barriers to entry into the market, when in fact low barriers to expansion by firms already in the market mean that the firm with a high market share has no market power.

In the same way that sunk costs are key to the analysis of barriers to entry, they are key to the analysis of barriers to expansion. If a firm would need to incur significant sunk costs to expand its output, then it probably faces significant barriers to expansion. However, it is quite possible that there could be significant sunk costs to entering a market, but low sunk costs to expanding output, once in a market. Two examples should make this clear. When branding

contrast, endogenous sunk costs are not predetermined in the same way. Rather, the level of endogenous sunk costs incurred is determined by the firms themselves. For example, the amounts that a firm is prepared to spend on research and development or on advertising are not usually pre-determined but are commercial decisions for the particular firm to make. The level of expenditure a firm will undertake in incurring endogenous sunk costs will typically depend on the effect that such spending has on consumer demand for its products. Where entry costs are endogenous, there arises the possibility that competition between firms will lead to a competitive escalation in such expenditures. Under these circumstances, such escalation can imply that some industries become strategically concentrated. This can lead to firms having high market shares even though they are engaged in fierce competition with their rivals.

58 Judgment of the European Court of Justice, Case C-27/76, United Brands, supra note 1 at para. 122. 
matters, barriers to entry can be high but barriers to expansion low. Firms often need to incur significant sunk costs (usually of advertising) to create a brand and this may be a prerequisite for entering a market. However, once the firm has established its brand and is in the market, expanding sales may not require significant sunk costs. A second example is that when investment is very "lumpy", 59 it may be necessary to incur large sunk costs to enter a market, but then the costs of expanding output to full capacity may be very low. Of course, once such a firm reaches full capacity, the lumpiness of investment means that it then faces high barriers to further expansion.

Excess capacity can be relevant for a finding of dominance. If other firms have excess capacity, this means they are likely to have low barriers to expansion and so are able to undermine any attempt by a large firm to exert market power by restricting output. This was noted by the Court in Hoffmann-La Roche: ${ }^{60}$ "the existence of considerable unused manufacturing capacity creates potential competition between established manufacturers".

\section{Economies of scale/scope/network effects}

In the presence of large economies of scale and economies of scope, a potential entrant may be deterred or delayed for a substantial period of time from entering the market due to the perceived difficulty of competing successfully against the incumbent who has already attracted such scale/scope economies (e.g., due to the need to reach a minimum viable scale of production relative to the size of the market for entry to be profitable). Court cases like United Brands referred to above, or Commission decisions like BPB Industries plc. ${ }^{61}$ expressly refer to the large economies of scale from which the companies benefited, as a factor relevant for a finding of dominance.

The same considerations apply to network effects, ${ }^{62}$ for instance in those cases in which wellestablished players have reached the critical mass that is required for customers to perceive the network as a necessary asset. ${ }^{63}$

Any finding of market power on the basis of economies of scale/scope and network effects will need to take into account whether it may still be profitable for new entrants to operate efficiently and thus pose competition constraints on the incumbent player on the basis of a smaller scale of production.

59 Investment is said to be "lumpy" when the investment necessary to produce one unit of a good is very similar to the investment needed to produce many more units. For instance, if a firm needs to buy a very expensive piece of machinery before it can start producing any units, but this machine will then be able to produce, say, a million units, then investment is lumpy. If the size of the "lumps" is large relative to the size of the total market, then one should expect to see relatively concentrated markets.

60 Judgment of the European Court of Justice, Case-85/76, Hoffmann-La Roche v. Commission, supra note 1at para. 48.

61 Commission decision of 5 December 1988, BPB Industries plc., (1989) O.J. L10/50, para. 116.

62 See OFT guidelines, supra note 8, at para. 5.21 ("Network effects occur where users' valuations of the network increase as more users join the network. ... If customers benefit from being on the same network (e.g. due to incompatibility with other networks), an incumbent with a well established network might have an advantage over a potential entrant that is denied access to the established network and so has to establish its own rival network").

63 For a recent Commission decision discussing the importance of direct and indirect network effects in the assessment of dominance, see Commission decision Microsoft, supra note 28. 


\section{$\underline{\text { Superior technology }}$}

In ECJ cases like United Brands, ${ }^{64}$ as well as in past and more recent Commission decisions like Eurofix-Bauco v. Hilti ${ }^{65}$ and Michelin $I I,{ }^{66}$ account has been taken of the "indisputable technological lead" of the allegedly dominant undertakings, where such lead was normally the result of extensive investments derived from the company's superior financial resources. Without more, the fact of a company having developed, through its internal skills, a better technology than that of its rivals should not be sufficient in itself for a finding of dominance. This will be particularly the case when competitors could have replicated such allegedly superior technology, and most certainly in industries where innovation is not critical or where companies can effectively compete on the basis of mature technology. In general, any finding of market power on the basis of superior technology should be treated with caution, as such findings may send the wrong signal to industry that a company is being penalized for its superior skills. ${ }^{67}$

In our view, the same reasoning applies to intellectual property rights, which generally aim at rewarding companies for their efforts to innovate. Any reference to the patents held by a company as a factor conducive to market power should have previously taken due account of alternative paths - including teaming efforts - available for other companies active in the relevant markets to compete on an equal footing without necessarily infringing the company's patent rights. ${ }^{68}$ The same reasoning will apply to other IP rights, namely copyrights and trademarks. In our view, only in specific circumstances - e.g., markets characterized by the importance of product differentiation and where strong brand recognition is critical for success - should the existence of trademarks be afforded any real weight in a finding of market power.

\section{Control of essential assets/vertical integration/branding}

The fact that an entity has access to assets that, while important, are not indispensable and can be replicated; ${ }^{69}$ that a company is vertically integrated (see e.g., ECJ United Brands judgment $^{70}$ or the Michelin II Commission Decision ${ }^{71}$ ); or that a company has been able to build a reputation on the basis of projecting a strong image (see e.g., ECJ United Brands judgment $^{72}$ ) should not, on their own, be regarded as decisive for a finding of market power.

Judgment of the European Court of Justice, Case C-27/76, United Brands, supra note 1 at paras. 82-84. Commission decision of 22 December 1987, Eurofix-Bauco v. Hilti, (1988) O.J. L65/19, para. 69.

Commission decision, Michelin, supra note 49 at paras. 183-184.

The claim that a finding of dominance as such does not penalize a company since only abuses are prohibited is a hollow one, since companies found to be dominant will be prohibited to continue certain practices even where those practices are prevalent in the industry.

See, OFT guidelines, supra note 8 at para. 5.13 ("Intellectual property rights (IPRs) can be entry barriers, although this is not always the case. In particular, when an IPR does not prevent others from competing with the IPR holder in the relevant market, it would not normally be a barrier to entry. In those cases where IPRs do constitute a barrier to entry, it does not always imply that competition is reduced. Although an IPR may constitute an entry barrier in the short term, in the long term a rival undertaking may be able to overcome it by its own innovation. The short term profit which an IPR can provide acts as an incentive to innovate and can thus stimulate competition in innovation").

The issue of essential facilities is discussed in other sections.

Judgment of the European Court of Justice, Case C-27/76, United Brands, supra note 1 at paras. 69-81.

Commission decision, Michelin, supra note 49 at paras. 191-195

Judgment of the European Court of Justice, 27/76, United Brands, supra note 1 at paras. 91-93. 
Doing otherwise may lead to penalizing companies for their greater skills and foresight in meeting the conditions necessary for successful competition.

\section{Portfolio power/product range}

The Commission and the ECJ have considered product ranges in a vast number of cases. Mention has been made of "the fact that AKZO offered a range of products wider than that of its main rivals", 73 of Michelin's "special extent of its range of products" in Michelin $I,{ }^{74}$ and of the fact that "the Michelin brand is in a position to offer a wide range of different tyre products such that an ever increasing number of customer groups is reached". ${ }^{75}$ In the Tetra Pak II Decision, ${ }^{76}$ the Commission referred to the "diversity of [Tetra Pak's] products and geographical locations, which makes it less dependent on various fluctuations and allows it, if necessary, to make financial sacrifices on one or other of its products without affecting the overall profitability of its operations".

In general, the fact that a company has a broad range of product offerings on the market should not lead to a finding of dominance. Such a finding should only be made in those circumstances where it can be shown that a deep product range inevitably leads to barriers to entry, for instance due to significant cost savings reaped by the allegedly dominant entity on the relevant markets due to its greater portfolio, or due to measurable advantages relative to its competitors such as discounts across the board that cannot be matched by its competitors. In particular, it should not be enough to merely assert that a company's broad product range allows the company, for instance, to subsidize certain predatory activities. On the contrary, it is necessary to show that such use of a broad range of products is actually possible and likely. The mere existence of a deeper portfolio than that of competitors should not be sufficient to claim that a company is in a position of market power, even in cases where the allegedly dominant entity is the first - but not only - supplier of choice.

\section{Overall strength (financial power, profitability)}

In Hoffmann-La Roche ${ }^{77}$ the ECJ held that the fact that Hoffmann-La Roche was the world's largest manufacturer, that it was at the head of the largest pharmaceuticals group in the world, and that it had the largest turnover, had no bearing on the finding of dominance. However, other cases do afford importance to the overall size and weight of a company. For instance, in Michelin $I^{78}$ the ECJ referred to "the advantages which [Michelin] may derive from belonging to groups of undertakings operating throughout Europe or even the world. Amongst those advantages was the lead which the Michelin group has over its competitors in the matters of investment and research and the special extent of its range of products [...]".

73 Judgment of the European Court of Justice, Case C-62/86, AKZO v. Commission, supra note 41 at para. 58.

74 Judgment of the European Court of Justice, Case 322/81, NV Nederlandsche Industrie Michelin $v$. Commission, [1983] E.C.R. 3461, at para. 55.

75 Commission decision, Michelin, supra note 49 at para. 184.

76 Commission decision, Tetra Pak II, (1992) O.J. L 72/1, para.101.

77 Judgment of the European Court of Justice 85/76, Hoffmann-La Roche v. Commission, supra note 1 at para. 47.

78 Judgment of the European Court of Justice, Case 322/81, NV Nederlandsche Banden Industrie Michelin $v$. Commission, supra note 74 at para. 55; See also Commission decision, Michelin, supra note 49 at paras. 182-183. 
In $B P B$ Industries ${ }^{79}$ the Commission considered that it was necessary to consider "not only the position of BPB in the market but also its technological and financial resources [...]"

Any considerations that do not pertain directly to the relevant market under review should not be factored in to any analysis of market power. Despite some Commission and EC Courts' practice suggesting the contrary, it is argued that the same reasoning should apply to "deep pockets" claims or to claims about the alleged favoured access of the supposedly dominant entity to capital markets. Large multinational groups are in many instances publicly-traded companies, and are directly responsible vis à vis their shareholders - as well as vis à vis their creditors - for any conduct aimed at preserving an inefficient business unit to the detriment of the most profitable segments of the company's range of activities. While capital markets do not always exercise as tight a control as one would hope on large multinationals, the fact remains that -- again -- it would be necessary to demonstrate that subsidization across activities is possible and likely. Moreover, evidence would then need to be adduced to show that specific capital markets deficiencies would deny competitors access to comparable funds.

\section{(viii) Behavioural factors}

The conduct of an undertaking in the market normally relates to the issue of abuse, not to the assessment of market power. However, both the ECJ and the Commission have also taken behavioural factors into account when dealing with dominance. In United Brands, ${ }^{80}$ the ECJ ruled that in order to find out whether an undertaking is in a dominant position, "it may be advisable to take account if need be of the facts put forward as acts amounting to abuses without necessarily having to acknowledge that they are abuses". In both Michelin cases the Commission relied on Michelin's allegedly abusive practices as indicators of market power, noting that "as is often the case in situations such as that being examined here, the finding of a dominant position is supported inter alia by the evidence relating to the abuse of that position". 81

A reference in the context of dominance to behavioural conduct should be limited to those instances where it can be shown that the conduct of an undertaking would not be feasible and profitable for a firm without market power. Even in those cases, it is argued that behavioural factors should only be relied upon as a complement, not a substitute, to a proper analysis of market conditions that also point to the existence of high entry barriers. The consideration of the undertaking's behaviour beyond these rather exceptional cases would inevitably lead to the risk of running circular arguments: due to its conduct a company is found to be dominant; and dominance and the "special responsibility" inherent to dominant undertakings in turn lead to the conduct itself being catalogued as anticompetitive.

\section{(ix) Previous findings of dominance}

Previous findings of dominance do not directly relate to the issue of whether at the time of the investigation potential entrants or existing players may be deterred by barriers to entry.

79 Commission decision of 5 December 1988, BPB Industries, (1989) O.J. L10/50, para. 115.

80 Judgment of the European Court of Justice, Case C-27/76, United Brands, supra note1 at paras. 67-68.

81 Commission decision of 7 October 1981, NV Nederlandsche Banden-Industrie Michelin, (1981) O.J. L353/33, para. 35, see also Commission decision of 20 June 2001, Michelin, (2002) O.J. L 143/1, paras. 198-199. 
Past findings of dominance cannot be substituted for a proper current analysis of the facts. As noted by the Court of First Instance ("the CFI") in Coca-Cola, ${ }^{82}$ a finding of dominance is the result of an analysis of the structure of the market and the conditions of competition prevailing at the time in which the Commission adopts each decision. Thus, in the course of each Article 82 EC decision, the Commission "must define the relevant market again and make a fresh analysis of the conditions of competition which will not necessarily be based on the same considerations as those underlying the previous finding of a dominant position".

\section{F. $\quad$ Buyer power}

Any assessment of market power must necessarily take into account the issue of countervailing buyer power. In Italian Flat Glass, ${ }^{83}$ the CFI reproached the Commission for not having "even attempted to gather the information necessary to weigh up the economic power of the three [allegedly collectively dominant] producers against that of Fiat, which could cancel each other out".

The issue of dominance cannot be properly dissociated from an analysis of the extent to which buyers interact in practice with suppliers, and the extent to which customers can counteract supra-competitive prices imposed upon them by the allegedly dominant supplier. Even companies with large market shares in industries with high entry barriers may still lack market power, for instance in cases where any decrease in output/price increase could be immediately avoided by buyers strategically scaling back their purchases. The existence of buyer power may also be substantiated in instances in which one or a limited number of buyers are an essential outlet for the manufacturer's product, as well as in those cases in which buyers can themselves enter or sponsor entry into the market.

\section{Collective Dominance}

Economic theory teaches that market power can be enjoyed by a single firm, but can also be jointly enjoyed by two or more firms. A classic way of jointly exercising market power is the formation of a cartel. However, absent any cartel or agreement, certain market conditions can in themselves induce independent firms to jointly exercise their market power. This may in particular happen on oligopolistic markets where prices rise and output decreases as a result of individual decisions taken by the operators, which do however take account of their interdependence in the framework of repeated interaction. This in turn leads to losses in allocative efficiency similar to those resulting from a cartel without, however, any collusive agreement being entered into. ${ }^{84}$ This issue, often referred to as the "oligopoly problem" has given rise to substantial practical difficulties in both the EC and the US. ${ }^{85}$

82 Judgment of the European Court of First Instance, Case T-125/97 and T-127/97, The Coca-Cola Company and Coca-Cola Enterprises Inc. v. Commission, [2000] E.C.R. II-1733, paras. 81 and 82.

83 Judgment of the European Court of First Instance, Cases T-69/89, T-77/89 and T-78/89, Società Italiana Vetro SpA, Fabbrica Pisana SpA and PPG Vernante Pennitalia SpA v Commission, [1992] E.C.R. II-1403, para. 366.

84 It may also lead to losses in productive efficiency since firms in such oligopolies do not compete anymore and may not seek to achieve economies on the cost side, etc.

85 See V. Korah, "Gencor v. Commission: Collective Dominance”, (1999) 6 E.C.L.R 337. 
As regards EC competition law, the concern for such market structures is not recent. In Dyestuff ${ }^{86}$ and Woodpulp, ${ }^{87}$ the ECJ held that such practices could not be caught under the concept of "concerted practice" pursuant to Article $81 \mathrm{EC}$. The question subsequently arose whether the application of Article 82 EC to the abuse of a dominant position held by "one or more undertakings" could provide a basis for initiating legal action towards such market outcomes. Under the influence of the Commission, both the CFI and the ECJ upheld a "collective dominance" doctrine whereby anticompetitive oligopolistic outcomes could constitute an infringement of Article 82 EC (1). ${ }^{88}$ However, the Community Courts and the legislator have further stretched this concept so as to encapsulate a number of other market configurations which are distinct from oligopolistic coordination settings (2). These judgments and decisions raise important concerns (3).

\title{
A. Collective dominance and oligopolistic anticompetitive coordination
}

In Compagnie Maritime Belge, the ECJ explicitly held that the concept of collective dominance under Article 82 EC encompassed anticompetitive oligopolistic interdependence situations:

\begin{abstract}
"[...] the existence of an agreement or of other links in law is not indispensable to a finding of a collective dominant position; such a finding may be based on other connecting factors and would depend on an economic assessment and, in particular, on an assessment of the structure of the market in question (emphasis added)". ${ }^{89}$
\end{abstract}

Prior to this case, it was not clear whether oligopolistic interdependence in itself could be brought within the ambit of Article 82 EC because the Court required the evidence of "economic links", which seemed to require more than just oligopolistic interdependence. The reference to "connecting factors" and to the "economic assessment and, in particular, on an assessment of the structure of the market in question" clarified this point. ${ }^{90}$

In the same judgment, the ECJ clarified the test for a finding of collective dominance:

"It follows that the expression one or more undertakings in Article 86 of the Treaty implies that a dominant position may be held by two or more economic entities legally independent of each other, provided that from an economic point of view they present themselves or act together on a particular market as a collective entity. (...) So, for the purposes of analysis under Article 86 [now Article 82] of the Treaty, it is necessary to consider whether the undertakings concerned together constitute a collective entity vis-à-vis their competitors, their trading partners and consumers on a particular market. It is only where that question is

86 See Judgment of the European Court of Justice, Case 48/69, ICI v. Commission (Dyestuff), [1972] E.C.R. 619.

87 See Judgment of the European Court of Justice, C-89, 104, 114, 116, 117, 125-129/85, Ahlström Oy v. Commission (Woodpulp), [1993] E.C.R. I-1307

88 Lawyers and economists often refer to a similar concept under the name of "joint dominance". To date, however, the case law of the ECJ only refers to the concept of "collective dominance", which will thus be used for the purpose of the present study.

89 See Judgment of the European Court of Justice, Case C-365 \& 396/96P Compagnie Maritime Belge Transports SA v Commission, [2000] E.C.R. I-1365 at para. 45. There is in addition a rich body of case law adopted in relation to merger control. The case law adopted on the basis of merger control extensively refers to Article $82 \mathrm{EC}$ in support of its substantive findings. In Gencor, the reference to Article 82 made it clear that oligopolistic interdependence fell within the scope of Article 82 EC. See Judgment of the European Court of First Instance, Case T-102/96, Gencor v. Commission [1999] E.C.R. II-753.

90 See Judgment of the European Court of Justice, Compagnie Maritime Belge at para. 45. 
answered in the affirmative that it is appropriate to consider whether that collective entity actually holds a dominant position and whether its conduct constitutes abuse.".11

Two steps are thus necessary in order to find a collective dominant position. ${ }^{92}$ First, there must be a "collective entity". The finding of a collective entity is itself subject to the implementation of a threefold test that was laid down by the CFI in Airtours whereby there must exist (i) a certain amount of transparency; (ii) a retaliatory mechanism; and (iii) the absence of reaction by current and potential competitors as well as customers. ${ }^{93}$ Second, the identified collective entity must enjoy a dominant position. Classically, the assessment of dominance is made with reliance on market shares as well as the other parameters that were outlined above.

In response to a number of difficulties that appeared in latter cases, the CFI recently elaborated on the test. Among these, was the question whether the existence of competition between the members of an oligopoly ran counter to the finding of a collective entity and thus to the finding of collective dominance under Article 82 EC. ${ }^{94}$ The Commission seems to consider that it can find collective dominance even if there is a possible degree of competition between the parties. ${ }^{95}$ This view was recently confirmed in TACA where the CFI held that:

\begin{abstract}
"there can be no requirement, for the purpose of establishing the existence of such a dominant position, that the elimination of effective competition must result in the elimination of all competition between the undertakings concerned" ${ }^{\prime 96}$
\end{abstract}

\title{
B. Other settings in which collective dominant positions may be identified
}

Besides oligopolistic markets, the concept of collective dominance has also developed in different configurations. This has been so essentially for legal reasons.

91 This has been repeated by the CFI in the TACA ruling, see Judgment of the European Court of First Instance, Joined cases T-191/98, T-212/98 to T-214/98, Atlantic Container Line AB and Others $v$. Commission, not yet reported.

92 See on this, M. Jephcott and C. Withers, "Where to now for EC oligopoly control?", 22 E.C.L.R. 301; P. Nihoul et P. Rodford, EC Electronic Communications Law, Oxford University Press, 2004 at para. 3.341; M. Clough, "Collective Dominance - the Contribution of the Community Courts", in Essays for Judge David Edwards, Hart Publishing, 2003 at p.174.

93 See Judgment of the European Court of First Instance, Case T-342/99 Airtours plc v Commission [2002] E.C.R. II-2585 at para. 62 : “ [...] three conditions are necessary for a finding of collective dominance as defined: First, each member of the dominant oligopoly must have the ability to know how the other members are behaving in order to monitor whether or not they are adopting the common policy (...); Second, the situation of tacit coordination must be sustainable over time, that is to say, there must be an incentive not to depart from the common policy on the market.(...); Third, to prove the existence of a collective dominant position to the requisite legal standard, the Commission must also establish that the foreseeable reaction of current and future competitors, as well as of consumers, would not jeopardise the results expected from the common policy."

94 For a discussion of this, see S. Preece, “Compagnie Maritime Belge: Missing the Boat?" (2000) 8 E.C.L.R. 388. See also J. Temple Lang, "Oligopolies and Joint Dominance in Community Antitrust Law", (2001), Fordham Corp L. Institute (B. Hawk, ed.), 269.

95 See Commission decision of 16 September 1998, Trans-Atlantic Conference Agreement, (1999) O.J. L 95 pp.1-112 at para. 522. This position was also expressed in the Commission Notice on the Application of Competition Rules to Access Agreements in the Telecommunications Sector, (1998) O.J. C 265 of 22 at para. 79.

96 See Judgment of the European Court of First Instance, TACA, supra note 91 at para. 653. 
(i) Collective dominance as the cumulative effect of individual dominant positions on distinct markets

Initially, the concept of collective dominance seemed to apply only where one relevant market was concerned. This is apparent in the (often overlooked) wording of the CFI in Flat Glass where the Court held:

"[...] There is nothing, in principle, to prevent two or more independent economic entities from being, on a specific market, united by such economic links that, by virtue of that fact, together they hold a dominant position vis-à-vis the other operators on the same market (emphasis added). ${ }^{.97}$

Subsequently, the concept of collective dominance was extended to situations where several undertakings enjoyed a dominant position respectively on different markets. ${ }^{98}$ The reason for this extension is of a legal nature. Indeed, Article $82 \mathrm{EC}$ requires, for a finding of a dominant position, that there is a dominant position "within the common market or in a substantial part of it". In Almelo and La Crespelle, several firms of regional/local importance each enjoyed a dominant position on a number of distinct and narrow geographic markets. ${ }^{99}$ Taken one by one, the dominant position of each firm did not seem to affect a substantial part of the common market. However, in a fashion similar to the cumulative effect doctrine under Article $81 \mathrm{EC}$, the Court considered that it was possible to aggregate individual dominant positions on different markets under the concept of collective dominance, so that a substantial part of the common market was affected. ${ }^{100}$

This case law raises important legal questions. First, there is a great deal of uncertainty because the Commission never itself enforced Article $82 \mathrm{EC}$ in situations of this kind. These cases were raised through the Article 234 EC preliminary reference mechanism. Second, most of these cases could potentially have been dealt with under national law. ${ }^{101}$ It would thus be welcome if the Commission could clarify its position on this issue and state whether there is a "cumulative effect" doctrine under Article 82 when several small companies each hold a single dominant position on neighbouring geographic markets. In addition, the Commission should strive to explain why such situations of arguably a minor geographic importance should not be left to national law.

97 See Judgment of the European Court of First Instance, Case T-68/89, 77/89 and 78/89, SIV and others $v$. Commission [1992] E.C.R. II-1403 at para. 358.

98 As John Temple Lang observes, "joint dominance in one market is not the same as a series of national, (or other) markets in each of which there is one sole dominant undertaking", see J. Temple Lang, supra note 94 at p.318. The author points out, referring to Bodson, that there can be joint dominance situations, (...) "even if the number of companies involved is quite large, and would not otherwise be thought as constituting an oligopoly", at p.300.

99 Judgment of the European Court of Justice, C-393/92, Gemeente Almelo and others v. Energiebedrijf IJsselmij, [1994] E.C.R. I-1477; Judgment of the European Court of Justice, Case C-383/93, Centre d'insémination de la Crespelle v. Coopérative de la Mayenne, [1994] E.C.R. I-5077

100 This hypothesis is explicitly pointed out by P. Nihoul and P. Rodford, supra note 92 at para. 3.327 and following.

101 See P. Nihoul and P. Rodford, supra note 92 at para. 3.331. 


\section{Collective dominance short of the single economic entity doctrine}

A further setting where collective dominance situations have been found consists in undertakings related to the same group that operate at different levels within the supply chain (and thus on different markets ${ }^{102}$ ), but that are not sufficiently integrated to form a single economic entity and thus be found individually dominant. This situation, often referred to as "vertical collective dominance", arose in the Irish Sugar case. In that decision, the Commission was attempting to put an end to a series of abuses entered into by a supplier and its distributor. The latter was under the control of the former but did not reach the case law standard necessary to a finding of a single economic entity. ${ }^{103}$ Thus they formed two distinct economic units. Only a part of the anticompetitive practices could have been brought to an end pursuant to Article 81 EC because there remained anticompetitive practices that were purely unilateral to the distributor. These practices could not be caught under Article 82 EC either, because there was no evidence that the distributor held an individual dominant position. The Commission thus linked the practices of the distributor to the dominant position of the supplier by relying on the concept of collective dominance. In that situation the collective dominance concept offers a convenient device for the Commission to overcome legal obstacles.

The Irish Sugar judgement, although an isolated judgement, is problematic in several respects. It could indeed extend the "special responsibility" bearing on dominant undertakings not to impair competition, to their distributors and trading partners. ${ }^{104}$ While in Irish Sugar a number of factual elements suggested that the producer held a significant control (through close management relationships) over the distributor, it remains to be seen whether, in a case where control would not be so strong, undertakings could be considered jointly dominant. ${ }^{105}$ Absent any enforcement after the Irish Sugar case, there is some uncertainty whether the Commission will actively scrutinise the trading partners of dominant companies or whether it only intends to do so in very specific instances, such as the ones at stake in the case.

\section{(iii) Collective dominance and legislative/regulatory measures}

A number of plaintiffs have also tried to invoke the collective dominance concept in order to challenge national laws on the basis of Article 82 and 10 EC. In all these cases, the ECJ rebutted the claims. In Spediporto, Bassano and Sodemare, the Court considered that the national laws at hand could not lead to a collective dominant position, because the undertakings were not linked sufficiently so that there was no competition at all between them. ${ }^{106}$ The standard for holding that national legislation may create collective dominant

102 See J. Temple Lang supra note 94 at p.382.

103 See Judgment of the European Court of Justice, 73/95, Viho v. Commission, [1996] E.C.R. I-5457.

104 See G. Monti, "The Scope of Collective Dominance under Article 82 EC" (2001) 38, C.M.L.R. 131 at p.143.

105 See V. Korah, Introductory Guide to EC Competition Law and Practice, supra note 37 at 2.2.1 and 3.2.5.

106 See Judgment of the European Court of Justice, Case C-96/94, Centro Servizi Spediporto v. Spedizioni Marittima del Golfo, [1995] E.C.R. I-2883 at para. 34: "National legislation which provides for the fixing of road-haulage tariffs by the public authorities cannot be regarded as placing economic agents in a collective dominant position characterized by the absence of competition between them"; Judgment of the European Court of Justice, Case C-140/94, DIP and others v. Comune di Bassano del Grappa and others, [1995] E.C.R. I-3257, at para. 27: "National rules which require a licence to be obtained before a new shop can be opened and limit the number of shops in the municipality in order to achieve a balance between supply and demand cannot be considered to put individual traders in dominant positions or all the traders established in a 
positions is thus that the undertakings be sufficiently linked between themselves that they adopt the same conduct on the market, i.e. that they do not compete with each other.

In spite of the negative stance of the Court, a number of authors nonetheless argue that State liability cannot be excluded in theory. ${ }^{107}$ Some even call the Commission to bring enforcement proceedings against Member States that would, through legislation, create or strengthen a market structure that is conducive to anticompetitive behaviour (e.g. a collective dominant position that could lead to potential abuses). A clarification on this issue by the Commission would therefore be welcome.

\section{(iv) Collective dominance in sector specific legislation}

The concept of collective dominance has not only been applied in the context of EC competition law, but has also been given recognition in the context of sector-specific legislation. For instance, Article 15 of the Framework Directive on electronic communications provides:

"An undertaking shall be deemed to have significant market power if, either individually or jointly with others, it enjoys a position equivalent to dominance, that is to say a position of economic strength affording it the power to behave to an appreciable extent independently of competitors, customers and ultimately consumers". ${ }^{108}$

The Framework Directive provides a number of non exhaustive criteria for assisting the regulators in the assessment of collective dominance. ${ }^{109}$ While research had suggested that the risk of collective dominance in electronic communications industries was rather low, the Commission has recently approved National Regulatory Authorities' findings of joint dominance situations on the mobile communications markets. ${ }^{110}$ At any rate, the regulatory schemes adopted pursuant to the Framework Directive seem to be adequately equipped to deal with potential anticompetitive parallel behaviour.

municipality in a collective dominant position, a salient feature of which would be that traders did not compete against one another."; Judgment of the European Court of Justice, Case C-70/95, Sodemare and others v. Regione Lombardia, [1997] E.C.R. I-3395.

107 See G. Monti, supra note 104 at p.153 ; S. Stroux, "Is EC Oligopoly Control Outgrowing Its Infancy?" (2000) 23 World Competition 3 at p.22.

108 See Article 15 of the Framework Directive, supra note 12. These factors are, among others, the maturity of markets, stagnant or moderate growth on the demand side, low elasticity of demand, homogeneous product, similar cost structures, similar market shares, lack of technical innovation, mature technology, absence of excess capacity, high barriers to entry, lack of countervailing buying power, lack of potential competition, various kinds of informal or other links between the undertakings concerned, retaliatory mechanisms, lack or reduced scope for price competition.

110 See M. Armstrong, "The Theory of Access Pricing and Interconnection" in M. Cave, S. Majumdar and I. Vogelsang (eds) Handbook of Telecommunications Economics, V.I: Structure, Regulation and Competition, North Holland, 2002, pp.297-386. However, ComReg's (the Irish Telecommunications Regulator) recently found that Vodafone and $\mathrm{O} 2$ were jointly enjoying a dominant position in the wholesale market for access and call origination in Ireland (they collectively achieved a 94\% market share). The regulator accordingly imposed remedies on the two operators (they will have, among others, to provide network access following a reasonable request by an access seeker). This decision was approved by the Commission. See Commission decision of 20 January 2005, Access and Call Origination on Public Mobile Telephone Networks in Ireland, not yet published. See also for a similar finding by the French Competition Authority: Avis du 14 octobre 2004 relatif à une demande d'avis présentée par l'Autorité de Régulation des Télécommunications en application de l'article L. 37-1 du code des postes et communications électroniques. 


\section{C. $\quad$ Areas of concern}

\section{(i) Low level of enforcement of collective dominance under article $82 \mathrm{EC}$}

A distinctive feature of collective dominance under Article 82 EC is its low level of enforcement. The Commission has been extremely cautious in launching Article 82 proceedings on the basis of the collective dominance doctrine. Rather, the Commission seems to have focused the enforcement of the doctrine in different fields, i.e. merger control and sector-specific legislation.

In addition, among the few collective dominance decisions adopted by the Commission, there has been so far no Article $82 \mathrm{EC}$ case where oligopolistic interdependence was held to constitute a sufficient connecting element required for a collective dominant position. ${ }^{111}$ In most cases, the Commission was able to evidence close links between the companies and the Commission's reliance on the collective dominance concept might be explained by the willingness to circumvent Article 81(3) exemptions or immunity from fines. ${ }^{112}$ For the sake of legal certainty, the Commission should clarify whether it intends to enforce Article $82 \mathrm{EC}$ where only connecting factors in the form of pure oligopolistic interdependence exist. This would additionally provide useful guidance to MS competition authorities and courts which might (have) engage(d) in action against anticompetitive oligopolies on the basis of Article 82-like provisions. ${ }^{113}$

\section{The test for collective dominance in oligopolistic settings}

The two step approach suggested by the EC Courts requires the assessment of (1) a collective entity and (2) of a dominant position.

\section{The existence of a collective entity}

Pursuant to the case law, a collective entity may be found either when some "economic links" exist between the undertakings or when some "correlating factors" lead them to behave as a common entity. While the concept of economic links does not only cover oligopoly and can help finding collective dominance in other market configurations (i.e. Almelo, Irish Sugar etc.), the concept of correlating factors seems to exclusively target situations of oligopolistic interaction.

It is in relation to the latter concept that the legal certainty is less satisfactory. In Airtours, the CFI refined the legal test for tackling oligopolistic interdependence in the sense of tacit coordination under the ECMR. In Laurent Piau, the CFI recently made clear that this test was

111 See H. Haupt, "Collective Dominance Under Article 82 EC and EC Merger Control in the Light of the Airtours Judgment”, (2002) 9 E.C.L.R., 434 at p.438; See also M. Clough, supra note 92.

112 See T. Soames, "An Analysis of the Principles of Concerted Practice and Collective Dominance: A Distinction without a Difference?" (1996) 1 E.C.L.R., 24.

113 For instance, on the basis of complex monopoly-style investigations in the UK. 
also applicable in Article 82 proceedings. ${ }^{114}$ However, merger control has a number of features that make it different from Article 82 EC proceedings and it can be questioned whether the test should be enforced in a similar fashion or should be the same. ${ }^{115}$

A first issue concerns the onus of proof lying on the Commission. In the context of the ECMR, the Airtours conditions aim at predicting a risk of future tacit co-ordination. In contrast, the approach under Article $82 \mathrm{EC}$ aims at showing that parallel pricing has actually occurred because of market features that were conducive to tacit collusion. Truly, there is a risk of adoption of a flawed decision under the ECMR. However, under Article 82 EC, a risk also exists that a parallel price increase, for instance, be sanctioned where it does not result from tacit co-ordination (when, for instance, price competition was constrained because of national legislation or because the price increase was caused by underlying cost increases). ${ }^{116}$ For this reason, while one should tolerate a margin of appreciation under the ECMR given the predictive nature of the assessment, the standard of proof under Article 82 should be more stringent. Because information not available to the Commission in merger proceedings is available under ex post enforcement, it seems reasonable to require the Commission to establish with much caution the existence of tacit co-ordination.

This is particularly true with respect to the substantive conditions laid down in Airtours. As far as the second condition is concerned, the CFI specifically noted in Airtours that the Commission did not have to bring evidence of the existence of a specific retaliatory mechanism. Rather it just had to show that a potential retaliatory mechanism might give incentives to firms not to deviate. ${ }^{117}$ The backward looking nature of Article 82 allows a better assessment of whether the collective action is the direct consequence of the existence of a retaliatory mechanism. Therefore, the Commission should be required, unlike under the ECMR test, to show that a specific retaliatory mechanism existed and exerted a deterrent effect that led the oligopolists to stick to a common line of action.

Equally, the transposition of the third Airtours condition within Article 82 proceedings could be debated. Under this condition, the Commission should prove that the "foreseeable" reaction of current and potential competitors as well as consumers would not jeopardise the expected results of the common policy. However, if an anticompetitive effect resulting from an abusive practice has been observed, it probably implies that potential competition was not sufficient and that the jointly dominant undertakings could actually behave independently of their competitors, actual and potential, as well as consumers. ${ }^{118}$ Nevertheless, this does not mean that the Commission should not analyse the question of potential competition within

114 See Judgment of the European Court of First Instance, Case T-193/02, Laurent Piau v. Commission, at $\$ 111$ not yet published; R. Whish, Competition Law, $4^{\text {th }}$ Ed., (2001) Butterworths, at p.479; J. Temple Lang supra note 94; Jonathan Faull and Ali Nikpay, The EC Law of Competition, Oxford University Press, 1999; P. Nihoul and P. Rodford supra note 92;.M. Clough supra note 92 at p.174. See, also in TACA, the references to Gencor and Airtours at para. 652.

115 See, for a good presentation of these, J. Temple Lang supra note 94 at p.314.

116 It should be observed that parallel pricing is consistent with competition as well as with collusion. For instance, if all firms used the same inputs, then a cost increase in an input should feed through to all the firms raising their prices. As a matter of economics, the more competitive the market, the more the cost increase would be passed on.

117 This has been criticized by A. Nikpay and F. Houwen in "Tour de Force or a Little Local Turbulence? A Heretical View on the Airtours Judgment" (2003) 24 E.C.L.R., 193 at p.199.

118 See Id., who have criticised excessive reliance on this condition in the field of the ECMR. A fortiori, their line of reasoning could be extended to the backwards assessment under Article 82 EC. 
Article 82 proceedings. ${ }^{119}$ On the contrary, the Commission should strive to prove that the undertakings could effectively implement tacit coordination because of the absence of curtailing power from their customers as well as actual and potential competitors. A clarification on this issue would be welcome.

Another related issue concerns the degree to which - in support of its finding of a collective entity - the Commission should produce evidence that competition between the oligopolists is hampered. In Airtours, the CFI held:

"The evidence must concern, in particular, factors playing a significant role in the assessment of whether a situation of collective dominance exists, such as, for example, the lack of effective competition between the operators alleged to be members of the dominant oligopoly and the weakness of any competitive pressure that might be exerted by other operators."120

Recently, in TACA, the CFI held that:

"there can be no requirement, for the purpose of establishing the existence of such a dominant position, that the elimination of effective competition must result in the elimination of all competition between the undertakings concerned"121

The ruling is unclear because it does not say how much competition between the oligopolists should be hampered to lead to a finding of collective dominance. There could be, for instance, a risk that even where operators would compete on a number of parameters, they could be found to enjoy a collective dominant position. ${ }^{122}$ This is quite problematic. In certain industries, operators might not compete on price but they fiercely compete on a wide range of other parameters (quality, innovation, commercial services etc.) which should limit findings of a "collective entity". For instance, in the oil sector, or the tobacco sector, price competition is to a large extent constrained by the cost of raw material, the homogeneity of products or by public taxation. This does not preclude operators from competing fiercely on these markets. It is thus submitted that the Commission should not give enforcement priority to those markets, but rather focus on markets where there is a lack of effective competition on a large range of parameters.

\section{Assessment of dominance}

It is not obvious whether the assessment of collective dominance should be carried out in a similar fashion to that of individual dominance. ${ }^{123}$ In particular, reliance on market shares may not be as decisive in oligopolistic markets as it is with regards to the assessment of a single firm's market power. While an undertaking may be presumed to enjoy an individual dominant position if it has a very large market share, the finding of a collective dominant position may not be reached even in the presence of a very large market share. For instance, if the collective entity enjoys a $70 \%$ market share, but there is important product differentiation, a lack of transparency, the ability to exercise collective market power might

119 See G. Monti, supra note 104 at p.138.

120 See Judgment of the European Court of First Instance, Airtours supra note 93 at para. 63.

121 See TACA supra note 91 at para. 653.

122 See J. Temple Lang supra note 94 at p.315.

123 See G. Monti, supra note 104. 
not be realistic. This is why there should not be any presumption of collective dominance on the basis of the identification of a high collective market share in an oligopolistic market. 


\section{Conclusions - Policy Recommendations}

As a matter of policy, the Commission should be encouraged to explicitly clarify that dominance within the meaning of Article $82 \mathrm{EC}$ amounts to substantial market power.

The Commission should clarify how it proposes to take account of the "cellophane fallacy".

Absent any clear statement by the Court and the Commission on the concept of super dominance, it would be helpful if the Commission could clarify its approach to this issue.

Factors outside a relevant market (e.g. a wide product portfolio or financial power) should only be relied upon in an assessment of dominance, if their bearing on competition within the market has been adequately demonstrated.

For the sake of legal certainty, the Commission should clarify whether it intends to enforce Article $82 \mathrm{EC}$ where only connecting factors in the form pure oligopolistic interdependence exist.

The standard of proof of a collective dominant position under Article $82 \mathrm{EC}$ should be more stringent than under the ECMR.

If collective dominance is to be enforced under Article 82 proceedings, the Commission should not give enforcement priority to markets where there is some form of competition between the oligopolists, but rather focus on markets where there is a lack of effective competition on a large range of parameters. 